Monthly Progress Report

\title{
Building Thermal Envelope Systems and Materials (BTESM) \\ Progress Report for DOE Office of Buildings Energy Research
}

December 1990

\author{
Compiled by Gabrielle Burn \\ for \\ Jeffrey E. Christian, Program Manager \\ Energy Division
}

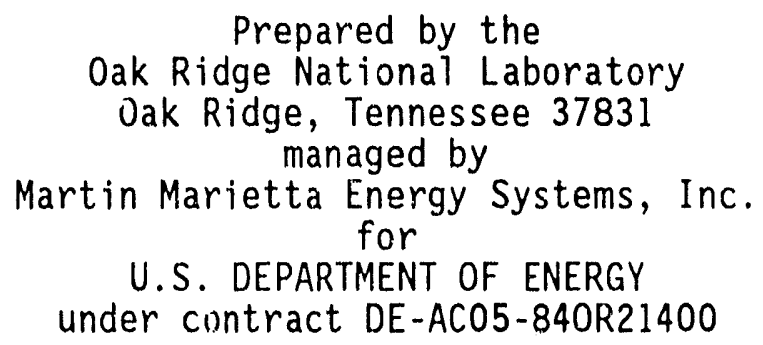

MASTER 
CONTENTS

I. BUILDING THERMAL ENVELOPE SYSTEMS AND MATERIALS (BTESM) Page

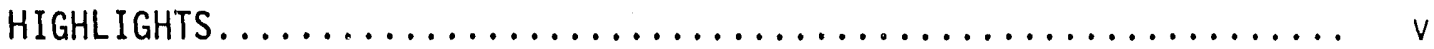

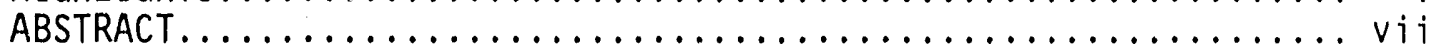

A. IMPLEMENTATION

1. Administration/Technical Support/Selected Projects....... 1

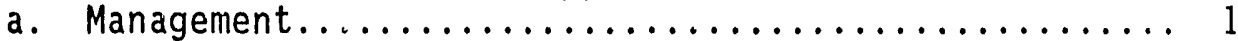

b. Reports Published This Period................. 2

c. Conferences and Meetings of Interest............. 3

d. Consultants Report........................ 4

B. BUILDING MATERIALS PROGRAM

Task B1. Advanced Materials Development

1.1 Evacuated Powder Panels....................... 8

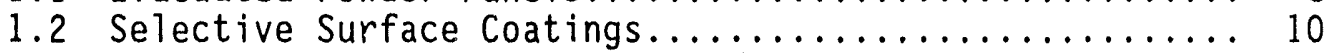

1.3 Joint Project with the Foam Industry.............. 11

Task B2. Existing Materials/Test Procedure

2.1 Test Procedure for High R, Super Insulations......... 18

2.2 ORNL Support Services to Industry \& DOE............ 19

Task B3. Building Materials Program Management Support

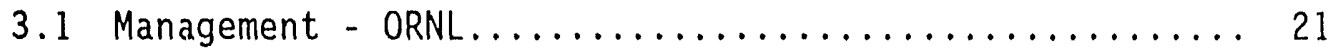

C. BUILDING ENVELOPE SYSTEMS

WALL PERFORMANCE

1. Thermal Mass Simplified Design Tool Assessment......... 24

2. Dynamic Evaluation of Thermal Bridges.............. 25

3. Validation of Moisture-Transfer Model............... 26

C. BUILDING ENVELOPE SYSTEMS (cont'd)

ADVANCED WALL SYSTEMS

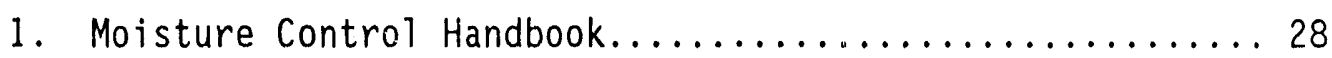




\section{FOUNDATION SYSTEMS}

1. Building Foundations Research Agenda.............. 29

2. Slab Foundation Benchmark Model.................. 30

3. Foundation Thermal Performance Simplified

Prediction Tool.............................30

\section{ROOF SYSTEMS}

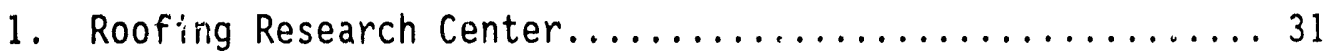

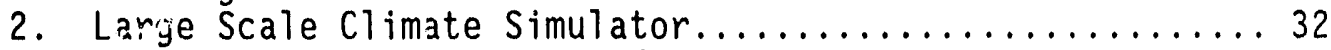

3. IEA Anriex on Low Slope Roof Systems............... 32

4. A.ttic Testing on the LSCS....................... 33

5. Field Testing of Isocyanurate Foams with Alternate

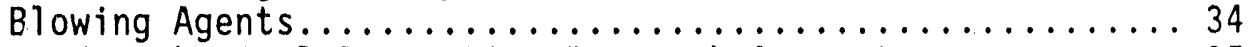

6. Roof Mechanical Properties Research Apparatus.......... 35

7. Roofing Industry Committee on Wind Issues............ 35

D. COOPERATIVE PROJECTS

1. Cooperative Industry/Government Research Project on Alternative Blowing Agents.................. 36 


\title{
HIGHLIGHT
}

\section{SECOND SYMPOSIUM ON INSULATION MATERIALS-- TESTING AND APPLICATIONS}

October 10-12, 1991

Gatlinburg, Tennessee

\section{SPONSORED BY ASTM COMMITTEE C16}

\section{ON}

\section{THERMAL INSULATION}

Call for Papers:

April 1, 1990

Abstracts Due: August 1, 1990

Abstract Acceptance Notification: September 1, 1990

Manuscripts Due:

January 2, 1991

STP Available:

October 10, 1991

\section{Session I: \\ Session II: \\ Session III: \\ Session IV: \\ Session V: \\ Session V: \\ Session VII: \\ Session VII: \\ Session $I X$ : \\ Session $X$ :}

\author{
Reflectives/Radiant Barriers/Radiation Control Coatings \\ Economics and Energy Impact \\ Long-Term Thermal Performance of Foams \\ Assessments and Properties of Foams \\ Convection in Fibrous Insulation \\ Tests and Models \\ Perfurmance Factors I \\ Innovative Insulations \\ Test Methods and Comparisons \\ Performance Factors II
}

For more information, please contact Symposium Co-Chairmen:

Ron S. Graves

Oak Ridge National Laboratory

Post Office Box 2008

Building 4508

Oak Ridge, TN 37831-6092

615/574-5978

FAX 615/574-7721
Don C. Wysocki

Mobay Corporation

Penn Lincoln Parkway West

Pittsburgh, PA 15205

412/777-2574

FAX 412/777-2758 
Building Thermal Envelope Systems and Materials (BTESM) Progress Report for DOE. Office of Buildings Energy Research

\section{ABSTRACT}

The Monthly Report of the Building Thermal Envelope Systems and Materials (BTESM) Program is a monthly update of both in-house ORNL projects and subcontract activities in the research areas of building materials, wall systems, foundations, roofs, and building diagnostics. Presentations are not stand-alone paragraphs every month. Their principal values are the short-time lapse between accomplishment and reporting and their evolution over a period of several months. 


\section{BUILDING THERMAL ENVELOPE SYSTEMS AND MATERIALS (BTESM)}

\section{A. IMPLEMENTATION}

\section{Administration/Technical Support/Selected Projects}

This task includes overall managenent for the BTESM Program with the emphasis on assuring that individual R\&D projects are performed via the best available expertise whether it be at universities, private labs, professional associations, or national labs (including ORNL). Also included are: implementation of major conferences, workshops and seminars, assurance of BTESM staff participation in committee work (BTECC, NIBS, ASTM, ASHRAE, etc.), BTESM National Program planning jointly with the total building community, technical support to DOE, and oversight of selected technical projects not delegated to other tasks.

\section{a. Management (Jeffrey E. Christian/Pat M. Love, ORNL)}

A new two-page reporting format for the monthly progress report will be implemented in January. Project highlights and interest items will be written up by each project leader and the report brief will be mailed to the distribution of the current mailing list. A detailed progress report will be issued only to the DOE sponsors.

A third Joint Work Statement for Cooperative Research and Development Agreement (CRADA) is in the process of being submitted to ORO for approval. Foamseal, Inc., Urethane Technology of Oxford, Michigan, has requested testing of their product to provide the thermal performance benefit of ceiling panels with a polyurethane adhesive manufactured by Foamseal and used in the construction of manufactured housing. Panels will be tested in the large Scale Climate Simulator (LSCS) with mechanical fasteners and with the polyurethane adhesive and with and without fiberglass insulation.

Thermal Performance of the Exterior Envelopes of Buildings $V$ Conference: The next planning meeting for this conference will be held January 21, 1991, from 9 to 12 noon in Room 513 of the New York Hilton. At this time, discussion will include site selection, final confirmation of chairs, and approval of a program plan. Other discussion will include topics for sessions. An information booth for this conference and the insulation materials conference will be open at the ASHRAE meeting in New York.

Second Symposium for Insulation Materials - Testing and Applications: This symposium, sponsored by ASTM Committee C 16, will be held October 10-12, 1991, in Gatlinburg, Tennessee, at the

Holiday Inn. Registration forms will be available in January. This is a busy time for Gatlinburg (peak Fall colors), located at the foot of the Great Smoky Mountains, so make your plans and reservations early. For more information, contact Co-Chairman Ron S. Graves at (615) 574-5978. See the highlight page for session topics. 
Robert L. (Bob) Wendt, Manager of the Roof Research Center, has accepted a new position in the site managers office at $\mathrm{K}-25$, effective January 1, 1991. Bob has been instrumental in promoting the Roof Research Center (RRC) and private industry collaboration during the past year. He helped plan and design the Roof Mechanical Properties Research Apparatus (RMPRA), the latest addition to the RRC facilities. He also provided invaluable assistance in the CRADA process, which is a new process for allowing industry testing at the RCC. We wish Bob well in his new position. Any questions about the RRC should be directed to Jeff Christian (615-574-5207) or Ken Wilkes (615-574-5931).

\section{EVENTS}

December 12

Dave Yarbrough, Tom Kollie, and Jeff Christian met with Peter Scofield in Washington, D.C., to discuss Radiation Control Coatings work-to-date, and future research possibilities on RRCS, switchable coatings, and dynamic walls.

December 12

Tom Kollie and Peter Srofield attended the December meeting of the ilisulaiion committee of the Appliance Research Consortium (ARC) to discuss development of a procedure to predict the lifetime of vacuum insulation in the air. The meeting was held in Washington, D.C. 


\section{c. CONFERENCES AND MEETINGS OF INTEREST*}

$\underline{1991}$

January 17-20: NAHB Annual Convention, At1anta, Georgia, Georgia World Congress Center.

January 19-23: ASHRAE 1990 Winter Meeting, to be held in New York, NY. For more information, contact Judy Marsha11 or Jan Young, ASHRAE Meetings, 1791 Tullie Circle, NE, Atlanta, GA 30329, or call (404) 636-8400.

April 17-19: Third International Symposium on Roofing Technology, sponsored by the National Institute of Standards and Technology; U.S. National Roofing Contractors Association; Canadian Roofing Contractors Association; National Research Council of Canada; International Waterproofing Association; CIB, and RILEM. The symposium will be held at the Montreal Convention Centre, Montreal, Quebec, Canada. For more information, contact Walte: Rossiter, NIST, Center for Building Technology, Building 226, Room B-348, Gaithersburg, MD 20899, or cal1 (301) 975-6719, FAX (301) 97ฐ-4032, TELEX TRT 197674 NIST WT.

October 10-12: Second Symposium on Insulation Materials--Testing and Applications, sponsored by ASTM Committee C 16, to be held in Gatlinburg, TN. For more information, contact Symposium Co-Chairmen: Ron S. Graves, Oak Ridge National Laboratory, P.0. Box 2008, Bldg. 4508, 0ak Ridge, TN 37831-6092, (615) 574-5978; or Don C. Wysocki, Mobay Corporation, Penn Lincoln Parkway West, Pittsburgh, PA 15205, (412) 777-2574.

$\underline{1992}$

December: Thermal Performance of the Exterior Envelope of Buildings $V$, to be held in the Florida area. Sponsors include DOE, ASHRAE, and BTECC. For more information, contact Pat M. Love, Co-Chairperson, Oak Ridge National Laboratory, P '. Box 2008, Oak Ridge, Tennessee 37831-6070, or call (615) 574-4346.

*Please send notices to Gabrielle Burn. 


\title{
d. CONSULTANTS
}

\section{ACEC RESEARCH AND MANAGEMENT FOUNDATION}

\author{
Jack R. Warner \\ President \\ Washingtun, D.C. 20005 \\ Subcontract ORNL/Sub-SE077/3 \\ Deliver by: 05-31-90
}

A new contract is pending. 


\title{
BTECC WORKSHOPS AND FEASIBILITY STUDY \\ BUILDING THERMAL ENVELOPE COORDINATING COUNCIL \\ NATIONAL INSTITUTE OF BUILDING SCIENCES
}

\author{
Bruce E. Vogelsinger \\ National Institute of Building Sciences \\ Washington, D.C. 20005 \\ Subcontract ORNL/SUb-SC111/10 \\ Deliver by: $12-31-90$
}

This contract has three tasks:

1. Feasibility of a Tracking System on Current Research and Publications on Building Thermal Envelopes.

A detailed scope of work was developed and distributed to potential subcontractors. Three proposals were reviewed and a subcontract was awarded to Energy Design Associates, Inc., Ansonia, New York. Work is under way, and the Materials RCC Committee of BTECC met on June 4 and reviewed the work of the subcontractor. A three-person review committee has been appointed. An interim report was submitted to the committee for review and comment on october 22. Tire report was reviewed by the Materials RCC Committee at a November 6 meeting.

Comments on the draft report have been transmitted to Energy Design Associates. The final report, originally scheduled to be completed on December 28, has been delayed and a new date is being established.

2. Workshop on Building Heat Flow Measurements.

The workshop was held at the Cold Regions Research and Engineering Laboratory, Hanover, New Hampshire, on May 22-23, 1990. Twentythree people attended the workshop. Papers from the authors were due Septamber 1, 1990. The last paper was received in November. Style editing has leen completed, and the papers have been returned to the authors for review and finai typing. Camera-ready papers are due back from authors on November 30. Some papers are still outstanding, and the authors have been urged to return the papers as soon as possible. Publication of the proceedings is now scheduled for February 28, 1991.

3. Workshop on Preventing and Repair of Condensation Damage in New and Existing Housing.

The planning and conduct of this workshop has been assigned to BTECC's Research Coordinating Committee on Moisture Control. Erv Bales, New Jersey Institute of Technology, and Bill Rose, University of Illinois, volunteered to co-chair the workshop. The RCC met on November 6 and has developed a draft program and selected the date of May 20-21, 1991, for the workshop. The workshop will be held in Washington, D.C., at the Washington Plaza Hotel. Mailing lists are being accumulated for promotional efforts. 
TASK B. BUILDING MATERIAL.S PROGRAM

The Building Materials Program includes work done at ORNL and work done by others on DOE-funded projects. The following pages include project reports for three areas:

\section{B1. ADVANCED MATERIALS DEVELOPMENT}

1.1 Evacuated Powder Panels

1.2 Selective Surface Coatings

1.3 Joint Project with the Foam Industry

\section{B2. EXISTING MATERIALS/TEST PROCEDURE}

2.1 Test Procedure for High R, Super Insulations

2.2 ORNL Support Services to Industry \& DOE

\section{B3. BUILDING MATERIALS PROGRAM MANAGEMENT SUPPORT}

3.1 Management - ORNL 
BUILDING

MATERIALS

PROGRAM

\title{
TASK B1. ADVANCED MATERIALS DEVELOPMENT
}

\subsection{POWDER EVACUAT':D PANELS}

\subsubsection{Polymer Barrier Materials \\ T. G. Kollio \\ Oak Ridge National Laboratory \\ Oak Ridge, Tennessee 37831-6092}

\begin{abstract}
We attended the December meeting of the insulation committee of the Appliance Research Consortium (ARC), which is a wholly owned subsidiary of the American Home Appliance Manufactures (A:AM) Association. The ARC wants to develop a procedure to predict the lifetime of vacuum insulation in air. We discussed a modified Statement of Work (SOW) with the insulation committee, which was accepted in principle. The final ARC decision on this project will be made by the Advisory Board of the $A R C$ at their January meeting. If approved, a Cooperative Research and Developmen't Agreement (CRADA) will be established between ORNL and the ARC.
\end{abstract}

The first rough draft of our summary report that reviews the ORNL efforts in panel technology has being reviewed by the authors. After revision in January, the second draft will be given an internal review by peers.

We are screening potential powder filler materials for panels. We desire to identify a powder that has a high thermal resistivity $(R)$ at high pressure, that is environmentally acceptable, and that is relatively inexpensive. Recent measurements on a very inexpensive powder yielded an $\mathrm{R}$ of $10.6 \mathrm{hr}-\mathrm{ft}^{2}-{ }^{\circ} \mathrm{F} / \mathrm{Btu}-\mathrm{in}$. at 0.038 Torr pressure; an $R$ of about 40 at this pressure was sought. The tapped bulk density of this powder was too high and it is being processed further to try and reduce it to increase $R$. 


\subsubsection{Fabrication of Evacuated Panel Insulation Using Thin Glass Sheets as the Barrier Material \\ Glicksman, Lanciani, Page, Moreno, Zammit Massachusetts Institute of Technology \\ Cambridge, Massachusetts 02139 \\ ORNL/SUb-09099/19}

Testing is continuing on filling a preformed glass shell with loose powder and compressing it under vacuum. At pressures near 300 millitorr, the powder begins to show signs of being compressed. Work is being done to improve the vacuum chamber to allow pressures as low as 100 millitorr.

The shells being tested are fabricaied froul 0211 microsheet glass supplied by corning, Inc. This glass has a thickness of .005 in. The success rate for forming the shells is $30 \%$ using this glass. Corning is providing samples of $.007 \mathrm{in}$. and $.009 \mathrm{in}$. thick glass to use in making glass shells using the technique developed at MIT. Although this thicker glass will lower the overall R-value of the sample, it is hoped that this will increase the success rate of the shells formed. 


\subsection{SELECTIVE SURFACE COATINGS}

\subsubsection{Radiation Control Coatings}

Robert W. Anderson

Robert W. Anderson and Associates, Inc. Boulder City, Nevada 89005

\section{and}

D. W. Yarbrough

Oak Ridge National Laboratory

Oak Ridge, Tennesse'e 37831-6092

ORNL/SUb-SE791/7

Continued "esearch on radiation control coatings (RCCS) was initiated during December. A joint effort involving R. W. Anderson and Asscciates, Warren Paint and Color Company, and Tennessee Technological University will produce RCC specimens of known composition for laboratory testing. A "Preliminary Assessment of Radiation Control Coatings for Buildings" (Anderson, Yarbrough, Graves, and Wendt), has been submitted for presentacion at the 1991 ASTM Symposium on Thermal Insulations. 


\title{
1.3 JOINT PROJECT WITH FOAM INDUSTRY
}

\subsubsection{ORNL Activities}

\author{
R. S. Graves, D. W. Yarbrough, and T. G. Kollie \\ Oak Ridge National Laboratory \\ Oak Ridge, Tennessee 37831-6092
}

Tests on thin specimens from boards foamed with CFC-11 and alternate blowing agents were run to provide thermal conductivity (k) data on specimens aged up to 465 days at $75^{\circ} \mathrm{F}$ and 393 days at $150^{\circ} \mathrm{F}$. Thirty thermal conductivity tests at a mean temperature of $75^{\circ} \mathrm{F}$ were conducted in the ORNL heat flow meter apparatus (HFMA) on planed specimens. This brings the total number of data points to 177 and the maximum aging time since planing to 465 days. The data were fitted by the method of least squares to equations that describe the foam aging process. These equations were interpolated to predict the thermal resistivity ( $R$, where $R=1 / k$ ) as a function of aging time at $75^{\circ} \mathrm{F}$ for 1.5 inch thick unfaced boards. These $R$-values are consistent with those reported in ORNL/TM11645 and increase the time of prediction from five years to ten years. The ten year predicted values range from 5.4 to $6.2 \mathrm{~h} \cdot \mathrm{ft}^{2} \cdot{ }^{\circ} \mathrm{F} / \mathrm{Btu} \cdot \mathrm{in}$.

A manuscript entitled, "In-Situ and Thin-Specimen Aging of Experimental Polyisocyanurate Roof Insulation Foamed with Alternative Blowing Agents," was submitted to the ASTM C 16 Second Symposium on Insulation Materials.

Comments on draft three of ORNL/TM-11720, "Interlaboratory Comparison of Four Heat Flow Meter Apparatuses on Planed Polyisocyanurate Boards Foamed with CFC-11," have been received and draft four will be prepared based on these comments.

Corrections based on reviewer comments have been made on draft four of ORNL/TM-11645, "Laboratory Test Results on the Thermal Resistance of Polyisocyanurate Foam Board Insulation Blown with CFC-11 Substitutes - A Cooperative Industry/Government Project," to produce the final document. 


\title{
1.3.2 Investigation of the Substitution of Environmentally Acceptable Blowing Agents in Foam Insulation: Means To Achieve Equivalent or Approved Energy Efficiency
}

\author{
Glicksman, Lanciani, Page, Moreno, Zammit \\ Massachusetts Institute of Technology \\ Cambridge, Massachusetts 02139
}

ORNL/Sub-09099/18

$\mathrm{KBr}$ pellets with coated samples have been weighed out and pressed. FTIR spectrometer analysis is under way. Average transmissivity of pellets is being compared to their thickness and mass. Bepex Corporation has finished hybridization on the core micropowders that were donated by Yorkshire Nachem, Dupont, GE, and Aldrich companies. The process coated the core powders with graphite donated by the Cabot Corporation. Analytical analyses in combination with the FTIR spectrometer experimentation will determine the proportion of micropowders to polyurethane foam material that should be added during foaming. Mobay Corporation and Dow Chemical Company have agreed to add these candidate micropowders to foam. Thirteen toner samples have also been donated to this project and will be considered for adition to foam if time permits.

Continued testing of Oak Ridge samples blown with CFC-11, CFC-123, and CFC-141b have been conducted. Density and extinction coefficient determination are being sought, and an inquiry of the extent of anisotropy of the five different samples will be evaluated. Data obtained from these samples will be used in the theoretical equation developed at MIT to predict a foams overall thermal conductivity and will be contrasted with the ongoing experimental data obtained from 0ak Ridge National Laboratory (ORNL).

The following is a summary of work related to the permeability studies of ORNL supplied foams. From each of the five board stock samples to be tested, three adjacent, $2 \frac{1}{2}$ inch diameter cores were cut. These cores will be used in the permeability tests and to determine foam geometry and density. Each core is identified A, B, or $C$. The average density for all cores was measured.

Cores $A$ were sliced into five sections of approximately 0.29 inch thickness. The density of each section was measured to evaluate gradient through the board. This information will be needed when the permeability test results are used in the foam aging model. The slices from cores $A$ will be stored at room temperature and density determinations will be made periodically.

Cores $B$ were sliced like cores $A$. Slice density was also determined. Sections of $B$ were then prepared for the Scanning Electron Microscope. Photomicrographs to determine cell diameter and cell walls thickness will be taken from three slices, corresponding to different distances 
from the facer. (Slice I, adjacent to the facer; S1ice II and Slice III, the central core).

Cores $C$ will be used in the permeability tests. The center of the foam core is sliced into two or more test samples. The outer foam was sliced as cores $A$ and $B$, and again slice density was determined. Results to date are given in the following figures and tables.

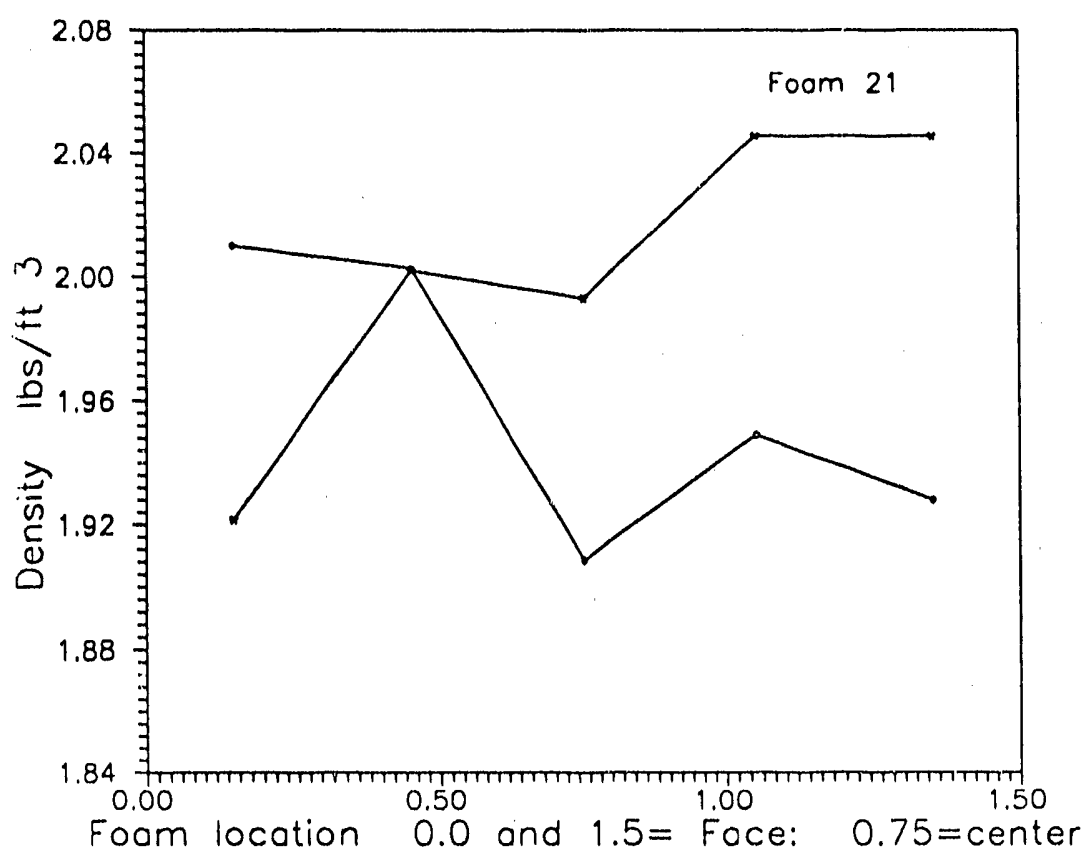



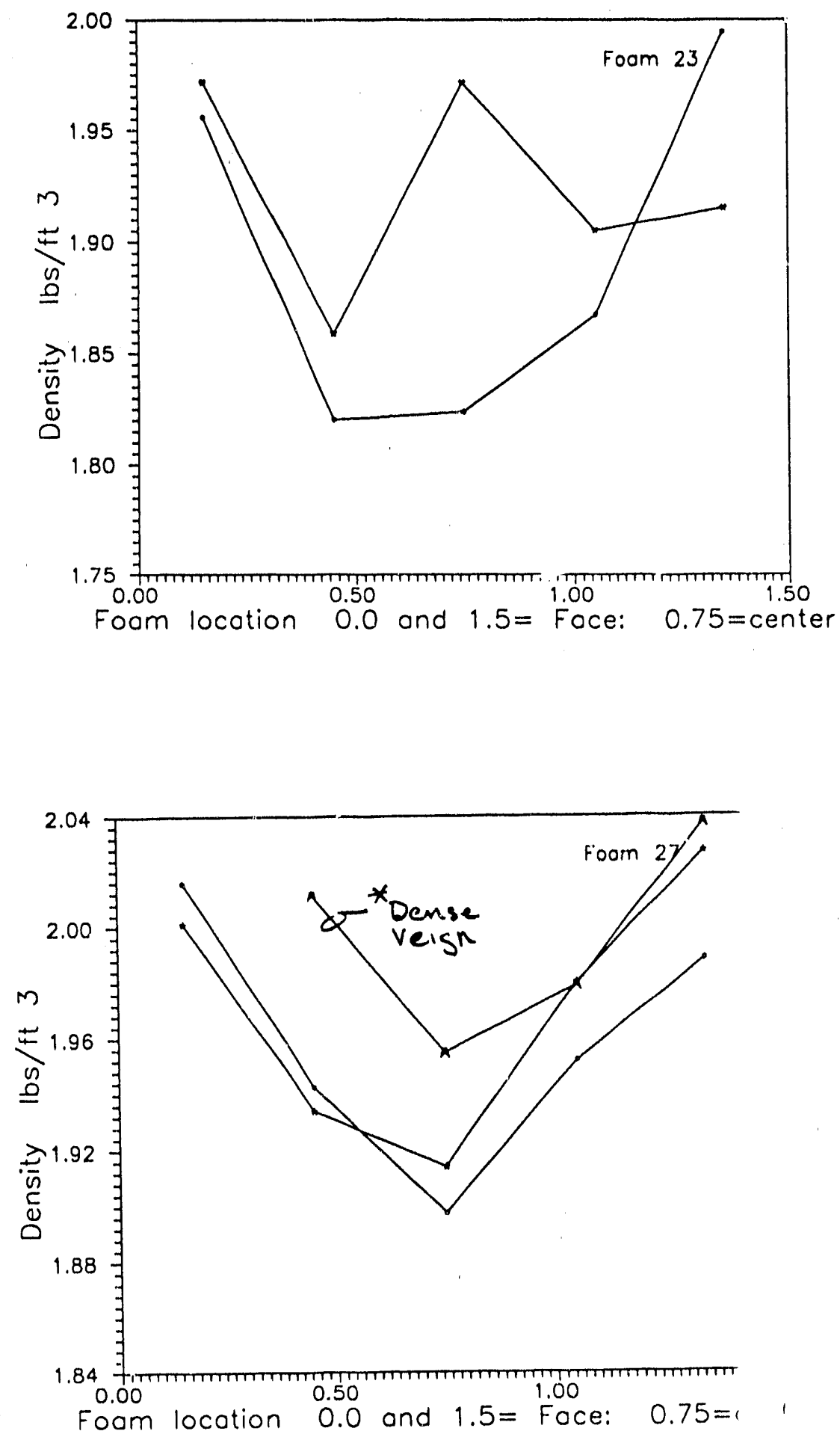

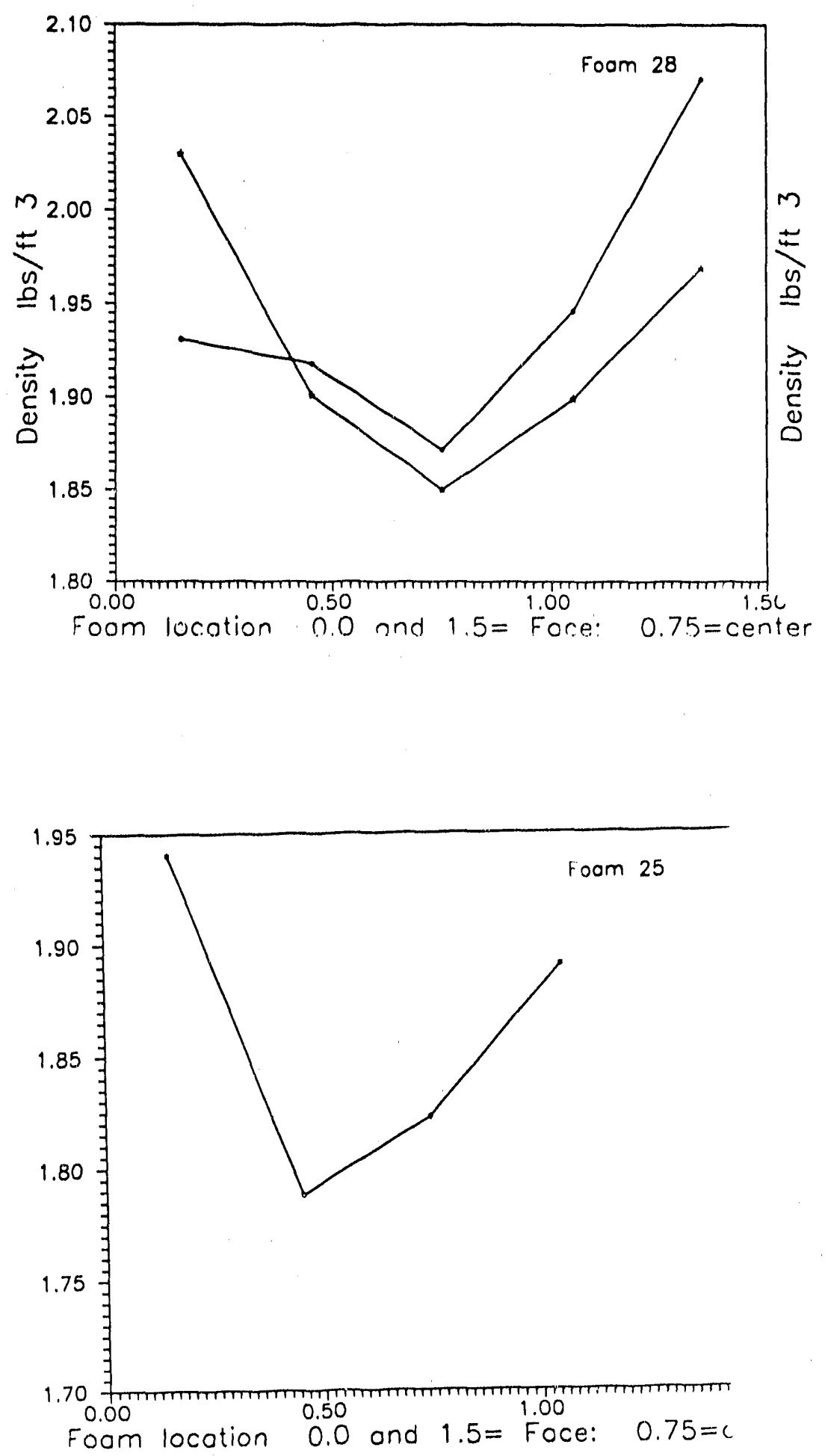


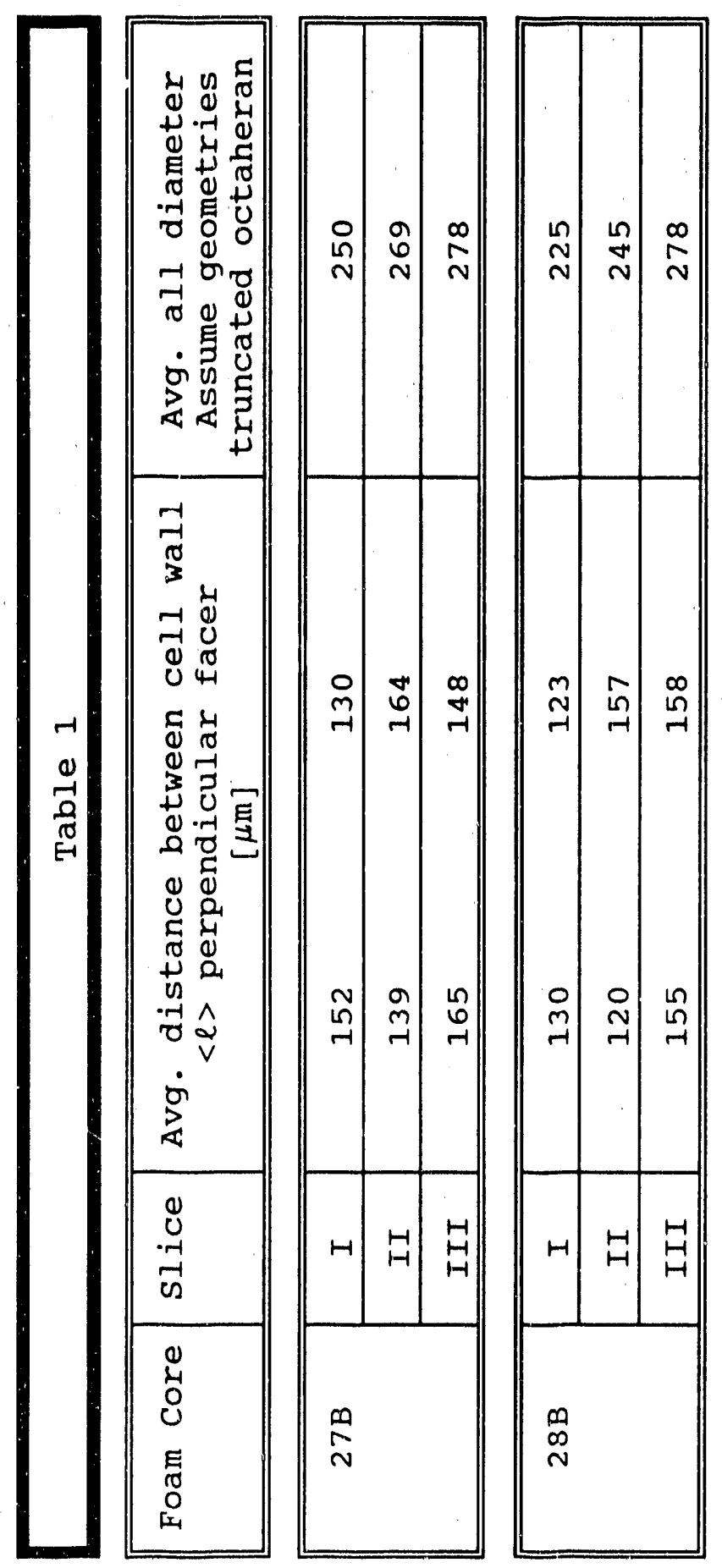




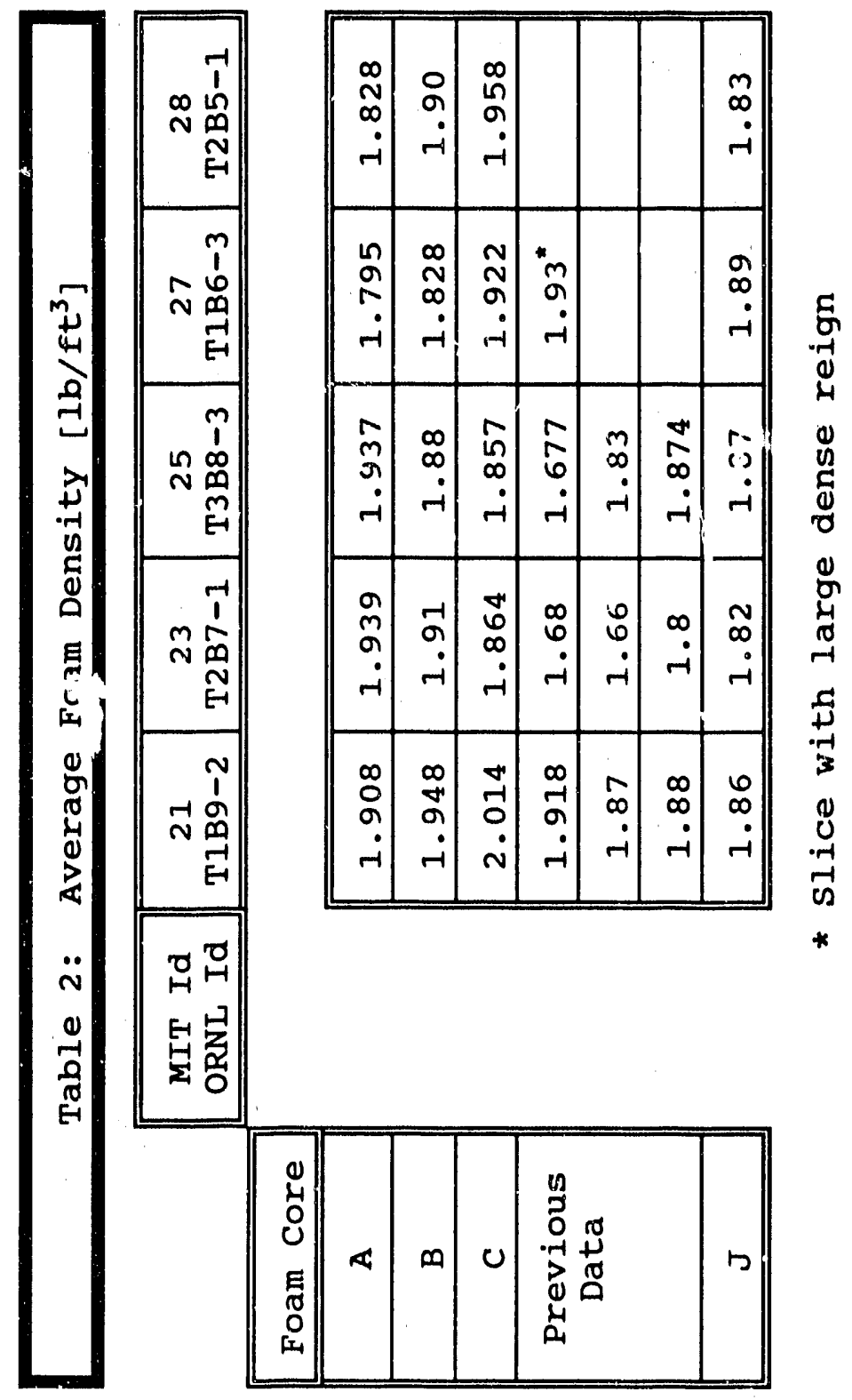


TASK B2. EXISTING MATERIALS/TEST PROCEDURES

\title{
2.1 TEST PROCEDURE FOR HIGH R, SUPER INSULATION
}

\author{
K. W. Childs and T. G. Kollie \\ Oak Ridge National Laboratory \\ Oak Ridge, Tennessee 37831-6092
}

\begin{abstract}
A project has been undertaken to produce a software package for use with data from the ORNL Heat Flow Measurement Apparatus (HFMA) to determine the R-value of nonhomogeneous insulation systems (e.g., evacuated panels with high-conductivity cladding). The HFMA device is widely used to determine the R-value of homogeneous insulation materials but cannot directly measure the R-value for nonhomogeneous materials. The software is intended to run on a hiah-end (80386) PC in order to satisfy a goal of making it widely availajle to testing labs across the country. The HEATING 7.1 conduction code has been used previously to perform similar calculations at ORNL on mainframe computer, and workstations.

Therefore, HEATING is being used as the basis for development of the new software package. The HFMA software package will have a much simpler user interface than HEATING and will perform an iterative solution which required multiple HEATING runs. A prototype of the software has been completed and is currently being tested on a $16 \mathrm{MHz}, 80386 \mathrm{PC}$ with a math coprocessor and 2 MB of memory. There was an initial concern that the software would not be practical to run on a PC because it would require too much memory or take too long to run. However, successful completion of a 7000 node test problem in approximately ten-and-a-half minutes has allayed these concerns. There is considerable development remaining to be done on this package, but results from the prototype are encouraging.
\end{abstract}




\title{
2.2 SUPPORT SERVICES TO INDUSTRY DOE
}

\author{
2.2.1 ORNL Activities \\ R. S. Graves, D. W. Yarbrough, and T. G. Kollie \\ Oak Ridge National Laboratory \\ Oak Ridge, Tennessee 37831-6092
}

Tests were completed in the ORNL HFMA on two extruded polystyrene boards that were foamed with HCFC-142b. These boards have now aged 511 days since manufacture and the R-values are about $5.02 \mathrm{~h} \cdot \mathrm{ft}^{2} \cdot{ }^{\circ} \mathrm{F} / \mathrm{Btu} \cdot$ in. Transient and steady-state tests are now under way in the unguarded thin-heater apparatus (UTHA) on companion specimens.

Four heat flux transducers were calibrated using the UTHA for Jeff Christian for use in foundation test sections. These HFTs were surrounded with special guards fabricated to match the thermal conductivity of the HFT composite. Three assemblies were run using Trymer-190 as backup boards and sensitivity values ranged from 0.44 to $0.53 \mathrm{flux} / \mathrm{MV}$.

Tests were initiated on fibrous-glass loose-fill specimens that were prepared when the attic test module was blown for testing in the LSCS.

Tests were completed on extruded polystyrene specimens foamed with HCFC-22. Thermal conductivity data were obtained in both the ORNL HFMA and the UTHA on specimens that have aged from 1067-1090 days. R-values range from 3.9 to $4.1 \mathrm{~h} \cdot \mathrm{ft}^{2} \cdot{ }^{\circ} \mathrm{F} / \mathrm{Btu} \cdot \mathrm{in}$. A manuscript entitled, "HCFC-22 as an Alternative Blowing Agent for Closed-Cell Foamboard Insulation," was submitted for the ASTM C 16 Second Symposium on Thermal Insulation. The paper includes test data taken over a three-year period and results of computer modeling. Plans were made to obtain additional property data to support future modeling efforts. Future work in this area will be coordinated by the newly formed task group on foam aging that is part of the Joint Industry/Government Research Project on HCFC in foam.

A manuscript entitled, "Steady-State and Transient Results on Insulation Materials," was submitted to the ASTM C 16 Second Symposium on Insulation Materials.

R. S. Graves (ORNL) and D. C. Wysocki (Mobay) are Co-Chairmen of the ASTM C 16 Second Symposium on Insulation Materials. All manuscripts are due at ASTM by January 2, 1991, to allow the Symposium proceedings to be available in October 1991. Several manuscripts have been submitted and the review process has begun.

A new correlation of reflective air space convective coefficients was used to analyze thermal data obtained by Holometrix, Inc., for the thermal resistance of reflective insulations. Modest improvement over a previous correlation (ORNL/TM-8891) was noted. The new correlation was used to develop a paper for the 1991 ASTM Symposium (Desjarlais and Yarbrough). 


\title{
2.2.2 Thermal Resistance Measurements and Data Base of CFC-Replacement Thermal Properties for Foam Insulation Products
}

\author{
R. Zarr \\ National Institute of Standards and Technology \\ Gaithersburg, Maryland 20899
}

ORNL/IA-21513/29

Progress Report for November 1990:

FY 1990 Milestone 2 (Measure Materials Using GHP and HFM).

Repeatability tests were conducted by a member of the Heat Transfer Group using the small HFM (plate size 305 millimeters). One specimen of extruded polystyrene was measured individually five times. Prior to measurement, the HFM was calibrated using a specimen of fibrous glassboard.

FY 1990 Milestone 3 (Final Report). A NIST Interagency Report entitled, "Calibration at $24^{\circ} \mathrm{C}$ of a Heat-Flow-Meter Apparatus having $610 \mathrm{~mm}$ Square Plates," was prepared and submitted for internal review at NIST.

The remaining work effort for this month was diverted to the 1990 ASTM C 687 Loose-Fill Round Robin and the development of five Calibrated Transfer Specimens for industry.

(1) Two final measurements of apparent thermal conductivity were conducted using the NIST one-meter guarded hot plates (GHP). Two measurements at a mean temperature of 23.8 degrees Celsius of cellulose loose-fill specimens were conducted. At the conclusion of the GHP tests, the apparent thermal conductivity of the specimens were determined in the large heat-flow-meter apparatus under the same test conditions.

(2) The final measurements were summarized and reported to Dr. David Smith at NIST in Boulder, Colorado.

(3) Ten measurements were conducted at 23.8 degrees Celsius using the NIST one-meter GHP on five specimens of low-density glass-fiber insulation. The specimens were supplied to industry as Calibrated Transfer Specimens.

FY 1989 Task B. Milestone 3 (Round-Robin with ORNL and JWRC). Work for this task was diverted to the above tasks. 
$21 / 22$

\section{B3. BUILDING MATERIALS PROGRAM MANAGEMENT SUPPORT}

\subsection{MANAGEMENT - ORNL}

We attended a meeting with the DOE/HQ staff to discuss the future direction of the program regarding radiation control coatings and switchable coatings. We al so discussed (with the DOE/HQ Materials Program Manager) the status of FY 1991 funding of the work at NIST and MIT, and the Materials Program budget for FY 1992 submitted by DOE to the Office of Management and Budget (OMB). The status of the new contract on radiation control coatings with $R$. W. Anderson and Associates was reviewed and steps made to expedite its placement. The approval procedure for the CRADA with the ARC was begun. A review of the recent heat transfer literature was used to identify potential materials projects. Papers on dynamic insulation were collected for review by project managemerit. 


\title{
C. BUILDING ENVELOPE SYSTEMS
}

\author{
ORNL Staff: \\ J. E. Christian, K. E. Wilkes, R. L. Wendt, \\ G. E. Courville, P. W. Childs, and K. W. Childs
}

This task includes work done at ORNL and work by others on DOE-funded projects on Building Envelope Systems and is divided into Wall Performance, Advanced Wall Systems, Foundation Systems, Roof Systems, and Building Diagnostics. Each of these project areas is treated separately on the following pages. 


\section{WALL PERFORMANCE}

\section{THERMAL MASS SIMPLIFIED DESIGN TOOL ASSESSMENT}

\section{J. E. Christian}

Oak Ridge National Laboratory

Oak Ridge, Tennessee 37831-6070

HUD has proposed that the HUD Minimum Property Standards adopt the CABD Model Energy Code. The thermal mass credit tables in the Modei Energy Code were developed at ORNL. A letter documenting the background development of these tables was sent to HUD for inclusion in the package of requested comments on this proposal for the public record. 


\title{
2. DYNAMIC EYALUATION OF THERMAL BRIDCES
}

\author{
D. Burch \\ National Institute of Standards and Technology \\ Gaithersburg, MD
}

ORNL/IA-21513/29

\section{Progress Report for November 1990:}

Fy 1989 Milestone 3 . The final report for this project, entitled, "Dynamic Evaluation of Thermal Bridges in a Typical Office Building," is undergoing review at the National Institute of Standards ani Technology. All other milestones for this project have been completed.

In this report, a finite-difference model is used to predict the steadystate and dynamic thermal performance of thermal bridges in a typical office building. The thermal bridges evaluated include: a built-up roof system with ceiling fasteners, a roof/wall interface, an insulated masonry cavity wall with metal studs, a floor slab that penetrates wall insulation, and a window frame/wall interface.

The steady-state analysis reveals that these typical thermal bridges increased the overall enve?ope heat transfer coefficient for the office building by $33 \%$. A thermal bridge is found to nave a large effect when it has a large cross sectional area that short circuits the thermal insulation of the building envelope.

In the dynamic analysis, a finite-difference model is used to numerically determine a complete set of conduction transfer function (CTF) coefficients for each of the thermal bridges. The mathematical procedure is to predict the heat transfer response of a thermal bridge when it is excited by a ramp excitation function. The heat transfer response for a triangular fulse is subsequently obtained by superimposing the responses for three ramp excitation functions to form a triangular pulse. A recursive relation is subsequently applied to the triangular-pulse response to determire first-order CTF coefficients. The validity of the CTF coefficients is demonstrated by accurately predicting the heat transfer response of each of the thermal bridges to a diurnal excitation function.

During the review of this report, a mathematical procedure was offered by a reviewer that permits the effect of the air film resistances to be removed from the CTF coefficients. In this study, procedures to obtain air-to-air CTF coefficients were originally developed. Computer programs such as TARP, BLAST, etc., require surface-to-surface CTF coefficients. This new contribution would permit the CTF Coefficients for chermal bridges to be incorporated into computer programs such as TARP, BLAST, etc The validity of this mathematical procedure is currently being checked out. 
3. VALIDATION OF MOISTURE-TRANSFER MODEL

\author{
D. Burch \\ Nitional Institute of Standards and Technology \\ Gaithersburg, Maryland 20899
}

ORNL/IA-21513/28

\title{
Progress Report for October 1990:
}

FY 1989 Milestone 3. Comp?ete Final Report on Sensitivity Analysis. A final report entitled, "An Analys is of Moisture Accumulation in a WoodFrame Cavity Wall Subjected to Winter Climate," is undergoing review at the National Institute of Standards and Technology.

Milestones 1 and 2. Complete Diffusion and Sorption Isotherm Measurement: for Ten Materials. NIST is currently carrying out moisture diffusion property measurements for ten common building materials. The ten materials include: (1) plain gypstim board, (2) white pine,

(3) vinyl-covered gypsum board, (4) asphalt-impregnated krait paper,

(5) wafer board siding with latex paint applied ta the exterior surfice,

(6) foam core sheathing, (7) wood fiber board, (8) exterior AC plywood,

(9) thick pressboard. and (10) asphalt-impregnated sheathing.

These property measurements are needed as inputs to the NIST Moisture Transfer Mode1. The model will be used to recommend good practices for controlling moisture in wall constructions as a function of indoor humidity and outdoor climatic conditions. The measurements are described below.

\section{Sorption Isotherm Measurements}

A sorption isotherm is a plot of the equilibrium moisture content of a material versus ambient relative humidity. These measurements are accomplished by placing smail specimens of the materials in pint-size jars above saturated salt-in-water solution that give different known ambient relative humidities. The specimens are permitted to remain in the jars until the moisture untake reaches a steady amount called the equilibrium moisture content. Separate sorption isotherms are obtained for specimens initially dry (adsorption isotherm) and for specimens initially saturated (desorption isotherm).

As of the date of this progress report, materials (1) through (7) have been completed. Materials (8) thorough (10) are currently under way.

\section{Permeability Measurements}

For these measurements, 6-in.-diameter specimens of the materials are instalied in a series of glass permeability cups (similar to an ASTM permeance cup) above a saturated salt-in-water solution that exposes the lower surface of the specimens to a particular ambient relative humidity. These permeability cups are placed inside glass desiccators 
above different salt-in-water solutions that expose the upper surface of the specimen to a small different relative humidity. In the series of permeability cups, small relative humidity differences are maintained across the specimens covering the humidity range from $0 \%$ to $100 \%$.

The relative humidity difference across the specimens causes water vapor to be transferred through the specimens. The water vapor transfer rate through each specimen is measured by periodically weighing the cups. The permeance is determined by dividing the measured water vapor transfer rate by the exposed surface area and the water vapor pressure difference. Special analysis procedures are utilized to subtract out the effect of the air film resistances. Permeability for each material is plotted as a function of the average relative humidity maintained across the specimen. Separate measurements are carried out at mean temperatures of $75^{\circ} \mathrm{F}$ and $44^{\circ} \mathrm{F}$.

As of the date of this reporting period, materials (1) through (7) have been completed. Materials (8) through (10) are in the process of being started. 
ADVANCED WALL SYSTEMS

\section{MOISTURE CONTROL HANDBOOK \\ Joseph Lstiburek \\ Dames \& Moore, Trow \\ Park Ridge, Illinois 60068 \\ ORNL/SUb-SD350/6}

The second draft of the Moisture Control Handbook, "New Low-Rise,

Residential Construction," was distributed to the Steering Committee for review. The committee's comments were requested to be returned to ORNI. by mail or fax by January 26, 1991. If there are considerable unresolved issues, a fina moisture control handbook review meeting will be held in February 1991. An executive summary remains to be written. A preliminary reading of the second draft indicates that the document. has made considerable progress towards a final product. The review committee comments received by January 26, 1991 will be reviewed and compiled by the Program Manager at ORNL and sent to Joe Lstiburek and John Carmody on February 1, 1991. 
FOUNDATION SYSTEMS

\section{BUILDING FOUNDATIONS RESEARCH AGENDA}

\section{J. E. Christian}

Oak Ridge National Laboratory

Oak Ridge, Tennessee 37831-6070

Construction has begun on the four foundation test sections in the Envelope Systems Research Apparatus. The heat flux transducer guards for eight transducers have been assembled and calibrated. Thermocouples have been installed in the interior insulated frame wall test section. Outside damp-proofing materials and protection boards have arrived. These will be used to cover the exterior insulation that extends above grade. Design drawings illustrating the instrumented panel layout for each test section are being developed. It is hoped that construction will resume as soon as the wet ground is given some time to dry.

The HUD has proposed that the HUD Minimum Property Standards adopt the CABO Model Energy Code. Some of the foundation insulation levels recommended in the MEC are based on ORNL/DOE research, and the Building Foundations Design Handbook is a listed reference. A letter describing the MEC background development of the foundation insulation energy efficiency levels was sent to HUD for the public record. 


\section{SLAB FOUNDATION BENCHMARK MODEL.}

K. E. Wilkes and J. E. Christian

Oak Ridge National Laboratory

Oak Ridge, Tennessee 37831-6070

No significant progress to report for the month of December.

3. FOUNDATION THERMAL PERFORMANCE SIMPLIFIED PREDICTION TOOL

Jeff Christian

Oak Ridge National Laboratory

Oak Ridge, Tennessee 37831-6070

No significant progress to report for the month of December. 
ROOF SYSTEMS

\title{
1. ROOFING RESEARCH CENTER
}

\author{
J. E. Christian \\ Oak Ridge National Laboratory \\ Oak Ridge, Tennessee 37831-6070
}

The RTRA summer data letter report on the Radiation Control Coating (RCC) was revised based on the internal review comments. A confidence check was made on the bottom surface temperature measurement. The RCC test is conducted on top of three $0.5 \mathrm{in}$. pieces of Douglas fir plywood. Close observation of the thermocouple mounting suggested that the thermocouple joint was not pressed hard against the surface. A second set of thermocouples was installed next to the existing set and tracked in parallel for a two-week period. The result was that the difference in temperature measurement is insignificant over a variety of weather: hot-sunny and cool-rainy. The ORNL computer program STAR will be used to conduct additional data checks. This provides detailed data of the RCC over 1.5 in. plywood compared to a plain black EPDM over 1.5 in. plywood. Hourly tabulated data are being used to validate algorithms in whole building energy simulation models. 


\section{LARGE SCALE CLIMATE SIMULATOR}

\section{P. W. Childs, K. E. Wilkes, and J. E. Christian \\ Oak Ridge National Laboratory \\ Oak Ridge, Tennessee 37831-6070}

Tests to characterize the newly' blown loose-fill fiberglass insulation, before the addition of the Attic Seal products, were completed. These tests were run under the same conditions as those completed previously on the loose-fill insulation.

Tests were completed on the first Attic Seal configuration. This configuration consisted of a 2 mil sheet of polyethylene placed on top of the loose-fill with a one-inch fiberglass blanket placed over the polyethylene. The next configuration will entail the addition of a radiant barrier placed over the blankets.

The climate chamber refrigeration system needed additional refrigerant after approximately two weeks of operation. The system was thoroughly leak checked and no leaks were found. It is suspected that the source of the leak may be in the coaxial cooler coil localind on the refrigeration skid outside. This presents a problem in that the coil is difficult to reach and is permanently enclosed in fiberglass insulation with a riveted aluminum shell. The shell will have to be cut off and the insulation removed before it can be determined if this is indeed the source of the leak. The repair is tentatively scheduled for the next 1 ull in the LSCS testing schedule, as a leak of this magnitude is unacceptable.

\section{IEA ANNEX 19 ON LOW SLOPE ROOF SYSTEMS}

George E. Courvilie

Oak Ridge National Laboratory

Oak Ridge, Tennessee 37831-6070

No progress to report for the month of December. 


\section{ATTIC TESTING IN THE LSCS}

\section{Kenneth E. Wilkes and Agnes Delmas \\ Oak Ridge National Laboratory \\ Oak Ridge, Tennessee 37831-6070}

A series of tests has been completed with the attic test module insulated with the second specimen of fibrous glass loose-fill insulation. Data obtained under winter conditions showed the same trends as were obtained with the first specimen of fibrous glass 1casefill insulation. The thermal resistance was observed to decrease significantly as the temperature difference across the insulation was increased. At large temperature differences, infrared scans of both the top surface of the insulation and the bottom of the gypsum board showed warm and cold patterns that are indicative of heat transfer by natural convection.

A series of tests has also been completed with the loose-fill insulation covered with a polyethylene film and a one-inch-thick layer of fiberglass blanket. At large temperature differences, this covering produced large increases in thermal resistance, and appeared to nearly eliminate heat transfer by natural convection.

A radiant barrier has been laid over the fiberglass blanket, and testing on this configuration is under way. 


\title{
5. FIELD TESTING OF ISOCYANURATE FOAMS WITH ALTERNATE BLOWING AGENTS
}

\author{
J. E. Christian and G. E. Courville \\ Oak Ridge National Laboratory \\ Oak Ridge, Tennessee 37831-6070
}

An ASTM technical paper on the in-situ and thin-specimen aging of experimental polyisocyanurate roof insulation blown with HCFCs was sent to ASTM. Field data collected on the RTRA up to December 2, 1990, wis included in this paper. One interesting observation from the HCFC-141b specimens under the black and white EPDM is that the field measurements detect a separation of the thermal performance after showing essentially no differences all summer. The laboratory measurements taken three weeks after this apparent difference occurred suggest that, once taken out and allowed to come to equilibrium in the laboratory, no measurable $k$-value difference is detected. A physical explanation for the field measurement behavior has not been found, although all of the differences occurred in the top board under the black membrane in the form of a very rapid drop in weekly average $k$-value. The blends continue to show little thermal performance differences.

The pure blowing agent sample $k$-values predicted by the laboratory slicing analysis for one year of age made at 200 days of age were compared to the actual measured values and found to be within \pm 1.5 percent.

A write-up on this research has been prepared for the Energy Division Annual Report. 


\title{
6. ROOF MECHANICAL PROPERTIES RESEARCH APPARATUS
}

\author{
Jeff Christian \\ Oak Ridge National Laboratory \\ Oak Ridge, Tennessee 37831-6070
}

Five $4 \mathrm{ft} \times 8 \mathrm{ft}$ boards, one of each of the polyisocyanurate test specimens, have been sent to Glen Gaddy, a graduate student at Johns Hopkins University. He will be conducting laboratory structural material property testing at the direction of Ton Smith from NRCA. Two net packs have been installed in the RMPRA, which will increase this facility's instrumentation data acquisition capacity from 60 channels to 260. One has been installed in the northwest corner and the other in the southeast corner. This month's walkover examination revealed no abnormalities. The month of December recorded 12.64 inches of rain ( 6.99 inches above average); no roof leaking occurred. The existing blisters on the BUR system have stabilized in size from 11/16/90. No new blisters were observed. The blister vents were not installed. Tom Hagen suggested the gas content under the blisters be sampled. This will be discussed at the February 4, 1991, Joint Steering Committee meeting. The fully adhered EPDM portion is beginning to show a $1 / 4 \mathrm{in}$. to $3 / 8$ in. upraised membrane directly over the joints between the insulation boards. A11 joints in this portion look the same.

\section{ROOFING INDUSTRY COMMITTEE ON WIND ISSUES}

George E. Courville

Oak Ridge National Laboratory

Oak Ridge, Tennessea 37830-6070

No progress to report for the month of December. 


\title{
D. COOPERATIVE PROJECTS
}

\section{COOPERATIVE INDUSTRY/GOVERNMENT RESEARCH PROJECT ON ALTERNATIVE BLOWING AGENTS}

\author{
G. E. Courville, D. L. McElroy, J. E. Christian, and R. L. Wendt \\ Oak Ridge National Laboratory \\ Oak Ridge, Tennessee 37831
}

This project is jointly supported by the Department of Energy, the Environmental Protection Agency, The Society of the Plastics Industry, the Polyisocyanurate Insulation Manufacturers Association, and the National Roofing Contractors Association. The objective of the project is to conduct comparative laboratory and field studies of isocyanurate foam roofing boards blown with conventional CFC-11 and with alternative blowing agents. The purpose is to identify performance differences, if any, between foams with alternative blowing agents and foam blown with CFC-11.

\section{MEETINGS AND PRESENTATIONS}

None.

\section{LABORATORY TESTING}

Tests on thin specimens from boards foamed with CFC-11 and alternate blowing agents were run to provide thermal conductivity ( $k$ ) data on specimens aged up to 465 days at $75^{\circ} \mathrm{F}$ and 393 days at $150^{\circ} \mathrm{F}$. Thirty thermal conductivity tests at a mean temperature of $75^{\circ} \mathrm{F}$ were conducted in the ORNL heat flow meter apparatus (HFMA) on planed specimens. This brings the total number of data points to 177 and the maximum aging time since planing to 465 days. The data were fitted by the method of least squares to equations that describe the foam aging process. These equations were interpolated to predict the thermal resistivity $(R$, where $R=1 / k)$ as a function of aging time at $75^{\circ} \mathrm{F}$ for 1.5 inch thick unfaced boards. These R-values are consistent with those reported in ORNL./TM-11645 and increase the time of prediction from five years to ten years. The ten year predicted values range from 5.4 to $6.2 \mathrm{~h} \cdot \mathrm{ft}^{2} \cdot{ }^{\circ} \mathrm{F} / \mathrm{Btu} \cdot \mathrm{in}$.

\section{FIELD TESTING}

An ASTM technical paper on the in-situ and thin-specimen aging of experimental polyisocyanurate roof insulation blown with HCFCs was sent to ASTM. Field data collected on the RTRA up to December 2, 1990, was included in this paper. One interesting observation from the HCFC-141b specimens under the black and white EPDM is that the field measurements detect a separation of the thermal performance after showing essentially no differences all summer. The laboratory measurements taken three weeks after this apparent difference occurred suggest that, once taken out and allowed to come to 
equilibrium in the laboratory, no measurable k-value difference is detected. A physical explanation for the field measurement behavior has not been found, although all of the differences occurred in the top board under the black membrane in the form of a very rapid drop in weekly average $k$-value. The blends continue to show little thermal performance differences.

The pure blowing agent sample $k$-values predicted by the laboratory slicing analysis for one year of age made at 200 days of age were compared to the actual measured values and found to be within \pm 1.5 percent.

A write-up on this research has been prepared for the Energy Division Annual Report.

\section{ROOF MECHANICAL PROPERTIES RESEARCH APPARATUS}

Five $4 \mathrm{ft} \times 8 \mathrm{ft}$ boards, one of each of the polyisocyanurate test specimens, have been sent to Glen Gaddy, a graduate student at Johns Hopkins University. He will be conducting laboratory structural material property testing at the direction of Tom Smith from NRCA. Two net packs have been installed in the RMPRA, which will increase this facility's instrumentation data acquisition capacity from 60 channels to 260. One has been installed in the northwest corner and the other in the southeast corner. This month's walkover examination revealed no abnormalities. The month of December recorded 12.64 inches of rain (6.99 inches above average); no roof leaking occurred. The existing blisters on the BUR system have stabilized in size from 11/16/90. No new blisters were observed. The blister vents were not installed. Tom Hagen suggested the gas content under the blisters be: sampled. This will be discussed at the February 4, 1991, Joint : ceering Committee meeting. The fulty adhered EPDM portion is beginning to show a $1 / 4$ in. to $3 / 8$ in. upraised membrane directly over the joints between the insulation boards. All joints in this portion look the same. 
- END-

DATE FILMED

$2 / 201$ 
